\title{
THE QUIET CENTRAL BANK DIPLOMACY AT THE BANK FOR INTERNATIONAL SETTLEMENTS (BIS): WHO GETS VOICE AND VOTE? ${ }^{1}$
}

\author{
Davi Augusto Oliveira Pinto²
}

\begin{abstract}
This paper assesses, from a diplomatic perspective and the point of view of Brazilian interests, the modus operandi of the Bank for International Settlements (BIS). The organization's banking activities are relatively secondary but contribute to its main goal of promoting central bank cooperation. Through historical inquiry and analytical review, the text examines the working methods of the BIS and identifies factors that explain its resilience for the last nine decades as a prime venue for contact and dialogue between central bankers. The BIS faces the challenge of balancing its traditional secrecy with contemporary requirements for greater transparency and legitimacy. Since the 1990s, the institution has significantly broadened its geographic reach, but the European weight is still disproportionate. Based on a thorough investigation, the article presents the shareholding structure of the BIS, which is not disclosed by the bank and remains anachronistically concentrated in the hands of its founders. In addition to discussing the varied formats of central bankers' meetings held regularly in Basel, the paper evaluates the representativeness of the organization's decision-making bodies and the power structure within them. Recent changes in the governance of the BIS, particularly in the composition of its Board of Directors and Management, although relevant, may be considered insufficient. The final section briefly describes Brazil's participation in the BIS and argues for sustained Brazilian engagement to reinforce the institution's role as it faces new challenges posed by technological innovation and, more recently, by the Covid-19 pandemic.
\end{abstract}

Keywords: Bank for International Settlements (BIS); central bank cooperation; Basel process; governance; shareholding structure; voting power.

\section{A DISCRETA DIPLOMACIA DOS BANCOS CENTRAIS NO BANCO DE COMPENSAÇÕES INTERNACIONAIS (BIS): QUEM TEM VOZ E VOTO?}

0 artigo avalia, a partir de perspectiva diplomática e do ponto de vista dos interesses brasileiros, o modus operandi do Banco de Compensações Internacionais (BIS). As atividades bancárias da instituição, relativamente secundárias, contribuem para a missão primordial do organismo de promover a cooperação entre bancos centrais. 0 texto examina os métodos de trabalho do BIS e, por meio de revisão histórica e analítica, identifica fatores que explicam a persistência da instituição ao longo de nove décadas como foro privilegiado de encontro e diálogo entre banqueiros centrais. O BIS enfrenta o desafio de equilibrar, por um lado, o sigilo que adota nas tratativas e, por outro, requisitos contemporâneos de maior transparência e legitimidade. Desde os anos 1990, houve significativa expansão geográfica da instituição, mas o peso

\footnotetext{
1. This article is based on a thesis presented in 2019 for the Advanced Studies Course of Brazil's Diplomatic Academy, Instituto Rio Branco, titled "Renovação versus anacronismo no Banco de Compensações Internacionais (BIS): a discreta diplomacia dos bancos centrais e a participação brasileira" ("Renewal versus anachronism at the Bank for International Settlements (BIS): the quiet central bank diplomacy and Brazilian participation"). Publication of the thesis, by Fundação Alexandre de Gusmão, is forthcoming. The views expressed here are those of the author and do not necessarily reflect those of Brazil's Ministry of Foreign Affairs.

2. Brazilian career diplomat and economist. E-mail:<davi@teologarte.com.br>. Orcid:<https://orcid.org/0000-0002-1446-7950>.
} 
europeu permanece desproporcional. Por meio de investigação minuciosa, foi elaborado quadro que revela a composição acionária do BIS, que não é divulgada pela entidade e continua anacronicamente concentrada nos membros fundadores. São descritas as variadas geometrias das reuniões de banqueiros centrais promovidas regularmente em Basileia e avaliadas a representatividade e a distribuição de poder nas instâncias decisórias do organismo. Recentes transformações na governança do BIS, particularmente na composição do Conselho Diretor e da Administração, embora relevantes, podem ser consideradas insuficientes. 0 texto relata brevemente a participação do Brasil e conclui com a defesa do continuado engajamento brasileiro, com vistas a reforçar o papel do BIS nesse momento em que surgem novos desafios relacionados à inovação tecnológica e à pandemia do novo coronavírus.

Palavras-chave: Banco de Compensações Internacionais (BIS); cooperação entre bancos centrais; governança; processo de Basileia; composição acionária; poder de voto.

\section{LA DISCRETA DIPLOMACIA DE BANCOS CENTRALES EN EL BANCO DE PAGOS INTERNACIONALES (BPI): ¿QUIÉN TIENE VOZ Y VOTO?}

El artículo evalúa, desde una perspectiva diplomática y desde el punto de vista de los intereses brasileños, el funcionamiento del Banco de Pagos Internacionales (BPI). Las actividades bancarias de la institución, relativamente secundarias, contribuyen a su misión principal de promover la cooperación entre bancos centrales. El texto examina los métodos de trabajo del BPI e identifica, a través de una revisión histórica y analítica, factores que explican su persistencia durante nueve décadas como foro privilegiado de diálogo entre banqueros centrales. El BPI enfrenta el reto de equilibrar su tradicional confidencialidad con los requisitos contemporáneos de una mayor transparencia y legitimidad. Desde los años 1990, ha habido una expansión significativa del alcance geográfico del organismo, pero el peso europeo sigue siendo desproporcionado. Una investigación exhaustiva permitió desvelar la composición accionaria del BPI, que la entidad no divulga y permanece anacrónicamente concentrada en los miembros fundadores. El artículo describe las diferentes geometrías de las reuniones de banqueros centrales celebradas regularmente en Basilea y evalúa la representatividad y la distribución de poder en los órganos de toma de decisión de la institución. Cambios recientes en la gobernanza del BPI, particularmente en la composición del Consejo de Administración y de la Alta Dirección, son relevantes, pero insuficientes. El texto informa brevemente sobre la participación de Brasil en el BPI y concluye con la defensa de un sostenido compromiso brasileño con la institución, para reforzar su papel en este momento de nuevos retos relacionados a la innovación tecnológica y a la pandemia del nuevo coronavirus.

Palabras clave: Banco de Pagos Internacionales (BPI); cooperación entre bancos centrales; proceso de Basilea; gobernanza; composición accionaria; derechos de voto.

JEL: E58; F02; F33; G28; N20; N40.

DOI: http://dx.doi.org/10.38116/rtm23art12

Data de envio do artigo: 4/8/2020; Data de aceite: 13/8/2020. 


\section{PROLOGUE}

A notion prevails that the Money Market is something so impalpable that it can only be spoken of in very abstract words, and that therefore books on it must always be exceedingly difficult. But I maintain that the Money Market is as concrete and real as anything else; that it can be described in as plain words; that it is the writer's fault if what he says is not clear.

Walter Bagehot, 1873

In the archives kept at the headquarters of the Bank for International Settlements (BIS), in Basel, the first mention of Brazil dates back to August 1931. The BIS had been established barely a year earlier. Its Board of Directors was discussing the possibility of offering participation in the institution's capital to non-European central banks. The meeting's minutes reveal that Brazil, which did not yet have a central bank, was already mentioned as a possible candidate: "the draft Statutes for the new Central Bank of Brazil contained an express stipulation authorising that institution to subscribe to the shares of the Bank for International Settlements". That quote is related to the mission to Brazil of Otto Niemeyer, a British specialist and member of the BIS Board, who presented economic policy recommendations to the Brazilian government and proposed statutes for a new central bank. ${ }^{4}$

The broad scope of the Basel institution's initial horizons is evident from its interest in the creation of central banks all around the globe. A memorandum presented to the BIS Board in 1933 mentions Niemeyer's involvement in the establishment of central banks in Argentina, Brazil, Egypt and New Zealand; and records progress in the creation of such institutions in Afghanistan, Canada, India and El Salvador. ${ }^{5}$ In 1931, the BIS and the Bank of England exchanged correspondence about contacts with the Paraguayan chargé d'affaires in London, who was seeking help for the creation of a central bank in his country. ${ }^{6}$ In a letter addressed in 1934 to the governor of the newly created central bank of New Zealand, the BIS president plainly expresses the organization's global ambitions: "if (...) there are operations in any other markets which you might find it convenient to transact through the central agency of the central banks, I wish you to know that our services are always at your entire disposition". ${ }^{7}$ Nevertheless,

3. "Minutes of the fourteenth meeting of the board of directors", BIS Archives, no 7.1 (1), 3 Aug. 1931, p. 2.

4. A senior Bank of England official, Niemeyer was BIS Board chairman (1937-1940) and vice-chairman (1946-1964). Article 31 (f) of the statutes proposed by Niemeyer (1931, p. 47) in his report stipulated that Brazil's central bank would be prohibited from buying shares, except those of the BIS. On his mission to Brazil, see Abreu (1974).

5. "Recent developments in the establishment of central banks", BIS Archives, no 3.9, 11 Dec. 1933, p. 1-7.

6. BIS Archives, no 3.9, Mar.-Apr. 1931.

7. "Letter from Leon Fraser to L. Lefeaux", BIS Archives, no 3.9, 23 Feb. 1934, p. 1. 
the admission of non-European central banks into the BIS, debated in the early 1930s, would only prosper decades later.

Brazil's central bank was finally created in $1964,{ }^{8}$ and soon started contacts with the BIS. In 1971, Brazilian diplomat Stélio Marcos Amarante, based at the embassy in Bern, was received at the BIS by D. H. Stapleton, assistant manager. Amarante informed that the embassy "had received a communication (...) indicating that the central bank of Brazil would like to become a member of the BIS and asking them to inquire what were the conditions of membership". Stapleton was not particularly receptive. He stated that, besides European countries, only the United States, Canada, Japan and Australia were part of the BIS; pointed out that no South American central bank was a member; highlighted the requirement included in the statutes that new members should "make a substantial contribution to international monetary co-operation and to the Bank's activities", leaving implicit the assessment that Brazil's nascent monetary authority did not fit the profile; and added that the admission of new members would be a matter for the BIS Board to decide. The embassy then sent a telegram to Brasilia, explaining that the BIS had an "eminently European character"; that admission was by invitation only; and that the BIS would not be likely to invite Latin American central banks.

\section{BANK OR INTERNATIONAL ORGANIZATION?}

Law is a flag, and gold is the wind that makes it wave.

Russian proverb

The two BIS buildings in Basel express the dual nature of the institution, both a bank and an international organization. The main tower hosts meetings between monetary authorities and banking supervisors from around the world and houses the Monetary and Economic Department, responsible for research tasks and for promoting central bank cooperation. The Banking Department, which manages the BIS capital and provides banking services to central banks and international organizations, operates in another building, five hundred meters away.

The most relevant aspect of the work of the BIS is to provide a vital forum for dialogue and consultation between the world's monetary authorities. Before mentioning any banking functions, the BIS statutes establish, as its first objective, the promotion of central bank cooperation..$^{10}$ But resources generated by the BIS as a bank surely contribute to its primary purpose. Compared to other international

8. Campos (1994, p. 661-674) chronicles the establishment and early evolution of Brazil's central bank.

9. "Banco Central do Brasil", BIS Archives, no 2.120, 17 Feb. 1971. Telegram 30/1971 from Brazil's embassy in Bern and telegraphic dispatch 28/1971 to Brazil's embassy in Bern, Foreign Ministry Archives, Brasília.

10. BIS (2019a, Article 3, p. 6-7). The BIS $(2000$, p. 3) explains that, "unlike a commercial bank, the prime objective of the BIS is to employ its resources in support of its public interest functions". 
organizations, the BIS enjoys greater independence from members, since it finances its work with the profits of its banking business. Instead of relying on members' contributions, the BIS pays out dividends to its shareholding central banks. ${ }^{11}$ Banking activities guarantee a generous budget, excellent material working conditions and big salaries, ${ }^{12}$ which attract highly qualified personnel. The remuneration paid to Board members - who are the world's top central bankers - for each session they attend may also help to ensure high-level participation in BIS bimonthly meetings and therefore reinforce their relevance. ${ }^{13}$

The important role played by the BIS is practically unknown. In addition to its deliberately low profile, its outdated name, related to payments - "settlements" of war reparations in the 1920s, does not help understand the organization's relevance. The BIS could well be called the "International Organization of Central Banks", a name that would make more evident its role as "the prime venue for international central-bank cooperation" (Borio et al., 2020, p. 2), just as there is the World Trade Organization (WTO) or the World Health Organization (WHO). It is often described as the "central bank of central banks", or, in the most precise form of the expression, the "bank of central banks". It is true that central banks are both its owners and main customers, but the latter definition is not satisfactory either, as it may suggest that banking functions are predominant. Perhaps a more appropriate analogy would be to say that, on a smaller scale, the BIS is for central banks as the United Nations is for foreign ministries. Both comprise multiple specialized committees and different decision-making bodies, are supported by a professional secretariat and promote busy annual general meetings.

\section{THE SECRETS OF CENTRAL BANK DIPLOMACY}

I, your Wizard, (...) am about to embark upon a hazardous and technically unexplainable journey into the outer stratosphere! To confer, converse, and otherwise hobnob with my brother wizards.

The Wizard of $\mathrm{Oz}$

The first meeting between Latin American and European central bank governors was held in Washington on September 29, 1966. Organized by the BIS and by

11. In 2019, the BIS (2019b, p. 74) paid a dividend of 245 special drawing rights (SDR) per share. Brazil's central bank, which holds 3,000 BIS shares, received SDR 735,000 in dividends, about one million dollars.

12. The annual salary of the BIS general manager, "before expatriation and other allowances", is CHF 696,100. The deputy general manager gets CHF 589,008 and department directors receive CHF 535,462 (BIS, 2019b, p. 85).

13. After all, not all countries are like Sweden, which in 2018 deducted from its central bank governor's salary about a hundred thousand dollars he had received from the BIS as fees for participating in the Board (Sveriges Riksbank, 2019, p. 95). The United Kingdom sets a similarly good example - since 1998, its central bankers are required to waive or to surrender to the Bank of England (2019, p. 60) any fees they get from the BIS. In its Annual Report, the BIS (2019b, p. 82) explains that the eighteen Board members received a fixed annual remuneration of around CHF 57,000 each and, additionally, around CHF 8,900 for each of the six annual Board meetings they attended. 
the Center for Latin American Monetary Studies (Cemla), a think tank created in 1952 by the central banks of Latin America, the meeting was attended by the first governor of the Central Bank of Brazil, Dênio Nogueira, and by officials from Argentina, Costa Rica, Chile, Mexico, Peru and Venezuela. On the European side, participated the central bank governors of Germany, Belgium, Denmark, Holland, England and Italy, as well as delegates from Spain, France and Switzerland.

Days later, Cemla director Javier Márquez forwarded a written summary of the debate to the BIS general manager, Gabriel Ferras, requesting that the four-page Spanish text be translated and sent to European participants, to stimulate reactions and dialogue. ${ }^{14}$ The text seems innocuous but reveals disagreements between the two sides, related to the supposed deflationary effects of industrialized countries' policies on developing economies. ${ }^{15}$ The BIS general manager's response lays bare the Basel institution's modus operandi up to this day. Ferras categorically rejected the possibility of circulating the text to European central bankers and established criteria to be followed in any new meetings:

I read the document with great interest and I think it reflects quite faithfully the substance of the discussions which took place on that occasion. I do not think, however, that it would serve a useful purpose to distribute it to the participating European governors. (...) such meetings can prove worthwhile provided that: (a) they are not institutionalised; (b) no record is kept of the discussions; (c) they retain the nature of an informal exchange of views. ${ }^{16}$

The following year, Alfredo Machado, governor of the central bank of Venezuela, wrote to Ferras to discuss the preparation of a new meeting between Latin American and European central bank governors on the sidelines of an International Monetary Fund (IMF) meeting to be held in Rio de Janeiro. Inquiring about the Basel institution's views regarding the meeting, the Venezuelan official pointed out that "it would be especially helpful to benefit from your opinion on what the nature of this session should be, its agenda, terms of reference, and so forth" ${ }^{17}$ In response, the BIS general manager repeated verbatim the arguments quoted above, insisting that meetings should be informal and with no written record, and added:

I do not think, therefore, that it would be advisable to fix in advance any agenda, terms of reference and so forth, especially bearing in mind that the governors participating in the Sunday afternoon discussions on the occasion of the Basle

14. "Letter from Javier Márquez to Gabriel Ferras", BIS Archives, no 1.26L, 10 Oct. 1966.

15. "Report attached to Javier Márquez's letter to Gabriel Ferras", BIS Archives, no 1.26L, 10 Oct. 1966, p. 1.

16. "Letter from Gabriel Ferras to Javier Márquez", BIS Archives, o 1.26L, 7 Nov. 1966.

17. "Letter from Alfredo Machado Gómez to Gabriel Ferras", BIS Archives, no 1.26L, 3 July 1967. 
Board meetings are accustomed to exchange their views in a very informal and spontaneous way and with no pre-established agenda. ${ }^{18}$

Since 1930, the BIS has worked under the assumption that, in order to keep its privileged status as a forum for central bankers' dialogue, it must prize confidentiality, informality and exclusivity. In 1979, a news leak of the content of Basel discussions caused outrage at a Fed meeting in Washington. The Fed chairman, William Miller, suggested that the issue should be brought to the attention of the BIS president: "I just don't think it is appropriate to go to the BIS and discuss in confidence our policies and have people go outside and start saying (...) this is what we discussed". ${ }^{19}$ That rare leak seems the exception that proves the rule. Central bankers usually recognize and value the privacy of BIS meetings, which allows them to share sensitive information and opinions openly.

A critical feature of the Basel framework is the purposely limited format, even to the detriment of inclusiveness. Swiss central banker Fritz Leutwiler, who as BIS president would have a major role in providing emergency loans to Mexico and Brazil during the 1980s Latin American debt crisis, stated that, "as a meeting center", Basel was "much more effective" than overcrowded IMF Interim Committee meetings, where there were over a hundred participants (BIS, 1980, p. 154). Blustein (2001, p. 290) considers that "the camaraderie and the bonds of personal trust that develop" in Basel are crucial to facilitate quick collaboration when financial market circumstances demand. ${ }^{20}$

Basel meetings can forge personal ties that do not necessarily correspond to the state of political relations between countries. After the Allies entered Rome at the end of World War II, Italian central banker Vincenzo Azzolini, a regular participant in BIS Board meetings in the 1930s, risked being sentenced to death as a result of proceedings against officials who had collaborated with fascism. Azzolini's defense asked the Basel institution for help, and both the BIS president, the American Thomas McKittrick, and the economic advisor, the Swede Per Jacobsson, provided written testimonials that may have contributed to the death penalty not being applied. Initially sentenced to thirty years in prison, Azzolini was pardoned in 1946 (BIS, 1980, p. 193).

18. "Letter from Gabriel Ferras to Alfredo Machado Gómez", BIS Archives, no 1.26L, 12 July 1967, p. 1. In a confidential letter dated December 9, 1969, Jean-Paul Sallé, IMF director in Paris, recorded Ferras' justifications for the BIS's unwillingness to send to the Fund a report about a Basel meeting: "it was unfortunately not the custom to prepare or issue - even to the participants - any document whatsoever following such meetings (...) such a procedure would give a formal status to the meeting, which everybody wished to keep as informal as possible". Available at: <https:// archivescatalog.imf.org/Details/archive/110092119>.

19. Available at: <https://www.federalreserve.gov/monetarypolicy/files/FOMC19790711 meeting.pdf\#page=4>.

20. Dutch central banker Jelle Zijlstra agrees: "the BIS is an institution (...) built on confidence. Of course, confidence is always a major factor in banking, but even more so here. Confidence, or perhaps we may go a step further and say friendship, between colleagues is absolutely essential in the BIS" (BIS, 1980, p. 17). 
BIS officials jokingly say that central bank governors meet in Basel to complain about their respective finance ministers. In other forums, such as the Group of Twenty (G20) and the IMF, central bankers are usually accompanied by ministers, but the BIS is their exclusive domain. Canadian central banker Louis Rasminsky, who attended informal BIS meetings from 1964 to 1973, considered that Basel discussions had a therapeutic effect. He claimed that, as central bank governor, he often found himself isolated from his own government in the task of pursuing monetary stability, but was glad to meet other central bankers who faced similar problems and shared the same assumptions (BIS, 1980, p. 62, 200). ${ }^{21}$ Dutch central banker Marius Holtrop shared that notion:

here I met with bankers on an equal footing, whereas in one's own country the Governor of the central bank is always somewhat isolated. He is partly a government figure and partly a banker (...). The bankers always have in the back of their mind that behind him there is, after all, the Minister of Finance, and the Government is inclined to think that, deep down, he is a friend of the bankers. (...) He doesn't have much opportunity to discuss problems on a basis of friendship and equality (...). That opportunity presented itself in Basle (BIS, 1980, p. 27-28).

In 1996, the Fed's Open Market Committee was considering the possibility of not renewing the bilateral swap agreements to which the United States was a party. There was fear that such a measure could generate tension with partner countries and be perceived as a lack of commitment to international cooperation. Fed chairman Alan Greenspan suggested taking advantage of meetings in Basel to informally probe the views of United States partners on those agreements: "it is very important for us to know if they think these are useless and obsolete appendages to the international financial system as distinct from a measure of embrace by the United States". Janet Yellen, future Fed chairman who attended the meeting, agreed with the suggestion: "it might be wise to look for an opportunity in Basle or elsewhere to discuss the future of these arrangements quietly with our central bank partners and to see what their reactions would be. I would not want to see needless tension created". New York Fed president William McDonough argued that, if the United States got rid of the agreements, no other mechanism would be needed, since international cooperation in Basel was quite sufficient:

in my view, what would replace it is what in a way already replaces it. A good many of us spend a fair amount of our time - I spend essentially 10 percent of my time - attending BIS meetings, (...) because of the close personal relationships that come from that. (...) if we have a problem with any of the people that the Chairman sees, say, at four meetings a year and I see at ten meetings a year, we are

21. Alan Blinder, former Fed vice chairman, corroborates the favorable assessment of BIS meetings in relation to other forums: "the talk is amazingly frank because there is no audience. (...) There is no gallery to play to... You know, central bankers cooperate across national borders better than governments do, and I think this is one of the reasons" ("Banking's Key Players", Washington Post, 28 June 1998). 
talking with someone we know very well. So what replaces the swap network is that personal relationship. ${ }^{22}$

Central bankers genuinely appreciate the BIS environment. The planet's top monetary authorities routinely reserve time on their busy schedules, every two months, to travel to Basel. Current BIS general manager Agustín Carstens (2018) reported visiting Basel on more than forty occasions during his time as Mexico's central bank governor, between 2010 and 2017. In an interview before ending his nine-year term at the head of the New York Fed, William Dudley commented that he was headed to Basel that evening for his 51st visit. ${ }^{23}$ Another frequent participant in BIS meetings was former Fed chairman Ben Bernanke (2015, p. 118-119):

international meetings, especially with my fellow central bankers, would occupy a substantial part of my time as chairman. We gathered a half-dozen times a year at the Bank for International Settlements. (The Fed chairman and vice chairman generally attended alternate meetings.) (...) After a day of formal meetings on the global economy, monetary policy, and financial regulation, we repaired to the BIS dining room for long, frank conversations over gourmet four-course dinners (each course with its own wine). For generations, the world's central bankers have formed a sort of club, of which I was now a member.

Besides being exclusive, confidential and well attended, Basel meetings seem to have at least some impact on the opinions and actions of participating central banks. That is shown by the outcome of the Fed's 1996 debate on swap lines. At the next gathering of the committee, Greenspan takes up the subject again: "at our last meeting, Bill McDonough and I were sent on a mission to the BIS to discuss the issue of swap arrangements". The transcript of the meeting then includes a sizeable blank gap, a sign that the content of the BIS discussions was suppressed. Nevertheless, what Greenspan goes on to say makes it clear that the abolition of bilateral swap agreements was not well received in Basel: "based on these conversations, it is my view that we should set aside the issue of the discontinuation of the swap network for the moment. We should return to this matter when a better opportunity presents itself". Even though it was not the Fed's preference, this course of action prevailed as a result of contacts at the BIS. McDonough's response to Greenspan makes that clear: "since the swap lines are essentially anachronistic, it would have been better if we had had a more receptive response. [But] your report on our meetings with them is absolutely accurate". ${ }^{24}$

Information obtained in BIS meetings can provide valuable input for national monetary policy decisions. Brazilian newspaper Valor Econômico reported

22. Available at: <https://www.federalreserve.gov/monetarypolicy/files/FOMC19960703meeting.pdf\#page=107>.

23. "Transcript: interview with New York Fed president William Dudley", The Wall Street Journal, 4 May 2018.

24. Available at: <https://www.federalreserve.gov/monetarypolicy/files/FOMC19960820meeting.pdf\#page=6> 
in January 2016 that the main topics on the agenda of closed-door meetings in Basel were the slowdown in the Chinese economy and the downward trend in oil prices, two factors that would contribute to lower inflation in Brazil. According to the newspaper, after participating in those meetings, central bank governor Alexandre Tombini changed his mind about the decision that was about to be made by Brazil's Monetary Policy Committee regarding interest rates. A few days later, instead of raising the policy interest rate Selic by 0.5 percentage points, as was expected by the market, the committee chose to keep the rate unchanged. ${ }^{25}$

Even discounting a certain amount of self-congratulation in the testimonies of Basel insiders, it seems that the BIS has proven to be a vital locus for central bank cooperation. But unlike the participating central bankers, not everyone approves the restricted and confidential nature of Basel meetings. It is not by chance that a significant portion of the available literature on the BIS consists of conspiracy theories about some sort of plutocratic cabal that manipulates the destiny of humanity from the top of a secret bank's tower in Basel, notions also fueled by the association of the BIS with Nazism during World War II. ${ }^{26}$

The BIS does not release official reports of what happens during Basel proceedings, but IMF and New York Fed officials who attended meetings in the past have regularly produced their own summaries of the discussions. After examining the records in the Fed's archives, Schenk attributes the confidentiality at the BIS to a supposed trade-off between transparency and effectiveness: "there is argument, quite frank argument, amongst the central bankers. And that's partly because they're not being recorded. (...) There is a move towards an understanding of best practice (...) that is possible in that kind of environment, that wouldn't be if it were more public" (Bordo and Schenk, 2017, p. 255-256). ${ }^{27}$ There are, however, reasonable arguments against undue secrecy at the BIS, regarding the lack of transparency and accountability to society. In 2011, a group of sixteen renowned academics and experts - including Armínio Fraga, Barry Eichengreen, Dani Rodrik, Hyun Song Shin, Kenneth Rogoff and Raghuram Rajan - prepared a long independent report on how to improve central banks' performance in light of the global financial crisis. One key proposal was the establishment, under the BIS umbrella, of a new central bankers committee, which, instead of the usual Basel format, would adopt a more formal and transparent model:

\footnotetext{
25. "Banco Central vê o mundo em espiral". By Claudia Safatle. Valor Econômico, 22 Jan. 2016.

26. A surprisingly well-researched example is Lebor (2013).

27. See also Schenk (2017, p. 87-88). The same positive impression of cooperative efforts within the BIS is generated by reading IMF reports about Basel meetings, usually prepared by Fund directors in Paris. See IMF (1963) for records of meetings held from 1951 to 1963; IMF (1966) for meetings held from 1964 to 1966; IMF (1970) for meetings held from 1967 to 1970; and IMF (1990) for meetings between 1986 and 1990.
} 
although central bank governors already meet regularly at the BIS, we recommend a substantial upgrade for our proposed committee from the current informal and closed-door format. Communication of central bank actions is important at the global level, just as it is for a domestic audience. (...) the current BIS format is not conducive to accountability (...) The need to issue periodic public reports can help central bankers identify and publicly air the inconsistencies in their policies. With time, this should encourage them to internalize some of the external consequences of their policies (Eichengreen et al., 2011, p. 31-32).

In view of such recommendations and of public opinion's demands for greater transparency and accountability, the BIS has already taken some steps towards opening up. There has been a significant recent expansion of membership, and emerging-market economies have started to take part in the institution's governance. In an interview at the beginning of his term as BIS general manager, Mexican Agustín Carstens (2018) stated:

we have made it our goal to present a more diverse and more human picture of the BIS (...). We want to become more approachable. (...) Obviously, there are some activities, also discussions, which by their nature are subject to confidentiality. But I can assure you that such business is less exciting than some people imagine (...) Central banks have in general become more transparent. We should reflect that trend and in turn become a more open and more transparent organization.

Despite the official speech, one should not expect the culture of secrecy that prevails at the BIS to be easily transformed. The exclusive central bankers' club operates on the basis of limited participation and utmost confidentiality. From the point of view of the oldest international financial institution, it is a formula that has stood the test of time, as evidenced by the constant presence of the world's top central bankers in Basel over ninety years. The BIS influences the work of central banks worldwide, including those that are not its members, but escapes the limelight by giving the impression that it has purely technical and bureaucratic functions, with no political implications. Unlike the IMF, whose activities can spark popular protests around the globe, the Basel institution remains far from the media spotlight and, for the time being, relatively immune to external pressures for greater openness.

\section{THE SLOW, GRADUAL AND SECURE EXPANSION OF THE BIS}

There are only two kinds of countries in Europe: small countries, and small countries that have not yet realized that they are small.

Paul-Henri Spaak, 1957

The BIS was born to manage war reparations between European countries. The original statutes provided that its Board directors had to reside in Europe or 
be able, in 1930, to attend regular monthly meetings in Basel. Of the seven founding members, only in the case of the five Europeans - Germany, Belgium, France, Italy and the United Kingdom - did central banks subscribe to the BIS shares. In the cases of Japan and of the United States, private banks purchased the shares. The Fed's participation in BIS meetings was merely informal until the 1990s. After World War II, as a result of the San Francisco Peace Treaty, Japan was forced to give up its membership and renounce all privileges it was entitled to as one of the BIS founders. ${ }^{28}$ The other nineteen members admitted between 1930 and 1931 were all Europeans.

During World War II, to ensure its survival, the BIS tried to maintain strict neutrality and please both sides of the conflict. That led to questionable decisions, among which to receive over three tons of gold that Germany had looted from occupied countries and Holocaust victims. Given the suspicions of BIS collaboration with the Nazis and the prospect of it becoming superfluous after the creation of the IMF, the famous Bretton Woods conference approved a resolution calling for the abolition of the Basel institution "at the earliest possible moment". The BIS helped post-war investigations, returned the Nazi gold and, with the support of European central banks, avoided extinction. But it also gave up its initial global ambitions and deliberately adopted a European character. ${ }^{29}$

In the post-war years, new European responsibilities gradually secured the place of the BIS in international monetary cooperation. It was entrusted with the administration of the European Payments Union, an arrangement created by the Organisation for European Economic Co-operation (OEEC), a forerunner of today's Organisation for Economic Co-operation and Development (OECD). From 1950 to 1960, to welcome into the Basel club all OEEC countries, the first wave of membership expansion was carried out, and five other European central banks became BIS shareholders: Iceland, Ireland, Portugal, Turkey and Spain (Toniolo, 2005, p. 319). In 1964, the European Economic Community (EEC), a precursor to the European Union, established its Committee of Governors of Central Banks. The EEC Commission would have preferred to have the committee meet in Brussels. But central bankers decided to take the meetings to Basel, where most of them already went regularly, even if it was in neutral Switzerland, outside of the EEC's jurisdiction. The meetings of EEC central bank governors were from then on held on the sidelines of regular BIS Board meetings, with a secretariat provided by the Basel institution.

28. The United Kingdom, in particular, insisted on excluding Japan (Yago, 2012, p. 132-134; Fraleigh, 1977). The United States embassy in Tokyo reports dealings with the Japanese government about this issue (Finn, 1977a; Finn, 1977b). 29. On the BIS management's efforts to convince United States authorities to allow the Basel institution to survive, see IMF (1948). Decades later, the BIS (1997a) published an explanatory note about its receipt of gold looted by the Nazis. 
Another important milestone was the formation, in the 1960s, of the Group of Ten (G10), a group composed of eleven industrialized countries: Belgium, Canada, France, Italy, Japan, Netherlands, Sweden, Switzerland, United Kingdom, United States and West Germany. The group, whose initial objective was to provide additional resources to the IMF, soon became an exclusive and informal coordination mechanism on subjects relating to the international monetary system. For other countries in the IMF, this represented a setback in global governance, since a restricted group started considering issues of interest to all members. ${ }^{30}$ Basel proved to be the ideal meeting place for G10 central bankers: eight of the eleven members were Europeans who already paid monthly visits to the BIS. The traditional Sunday meetings and dinners of the BIS Board became informal G10 meetings. Although they were not BIS members, Canadian and Japanese central bankers were invited to take part from 1964 onwards. The United States had not yet taken up its seats on the BIS Board, but Fed officials started visiting Basel regularly. In a confidential report dated April 9, 1968, the IMF director in Paris, Jean-Paul Sallé, described the BIS as "a restricted organization which tends to consider the interests of only a limited number of countries mostly the 'Ten'". ${ }^{31}$

The BIS played a central role in building a monetary union in Europe, which culminated in the creation of the European Central Bank (ECB) and the adoption of the euro as a common currency. In the 1970s, European central bank governors meeting in Basel decided to use BIS expertise to manage arrangements to limit exchange rate fluctuations between their currencies. Between 1988 and 1989, a committee chaired by Jacques Delors, then European Commission president, and comprising all EEC central bank governors and Alexandre Lamfalussy, then BIS general manager, met in Basel to propose a roadmap for achieving European monetary union. The Delors Report was the basis for the Maastricht Treaty, which formalized in 1992 the decision to move towards a single currency. In 1993, the EEC Committee of Governors of Central Banks, which had been meeting in Basel since 1964, was transformed into the European Monetary Institute (EMI). Lamfalussy, considered one of the "fathers of the euro", left the BIS to lead the EMI, which was transferred from Basel to Frankfurt in 1994 and became, in 1997, the European Central Bank.

In Figure 1, which shows the number of BIS members by continent, there is a sudden steep slope at the point corresponding to 1996. The biggest step in extending the BIS geography beyond European borders was taken that

30. In 1964, making reference to the G10, the BIS and the OECD, a United States government report commented that "the development of monetary institutions in which only rich countries participate has already aroused some suspicion and resentment on the part of the other 92 members of the [International Monetary] Fund" (Kaysen, 1998, annex).

31. Available at: <https://archivescatalog.imf.org/Details/archive/110092119>. 
year, when nine emerging-market central banks were invited to join the bank: Brazil, China, Hong Kong, India, Mexico, Russia, Saudi Arabia, Singapore and South Korea. The timing was no coincidence. The establishment of the ECB in Frankfurt effectively caused the BIS to expand its horizons. The focal point of European monetary cooperation was at last inside the European Union territory. To stay relevant, the traditional Basel institution had no choice but to become a global organization.

FIGURE 1

Number of BIS members by continent (1930-2020)

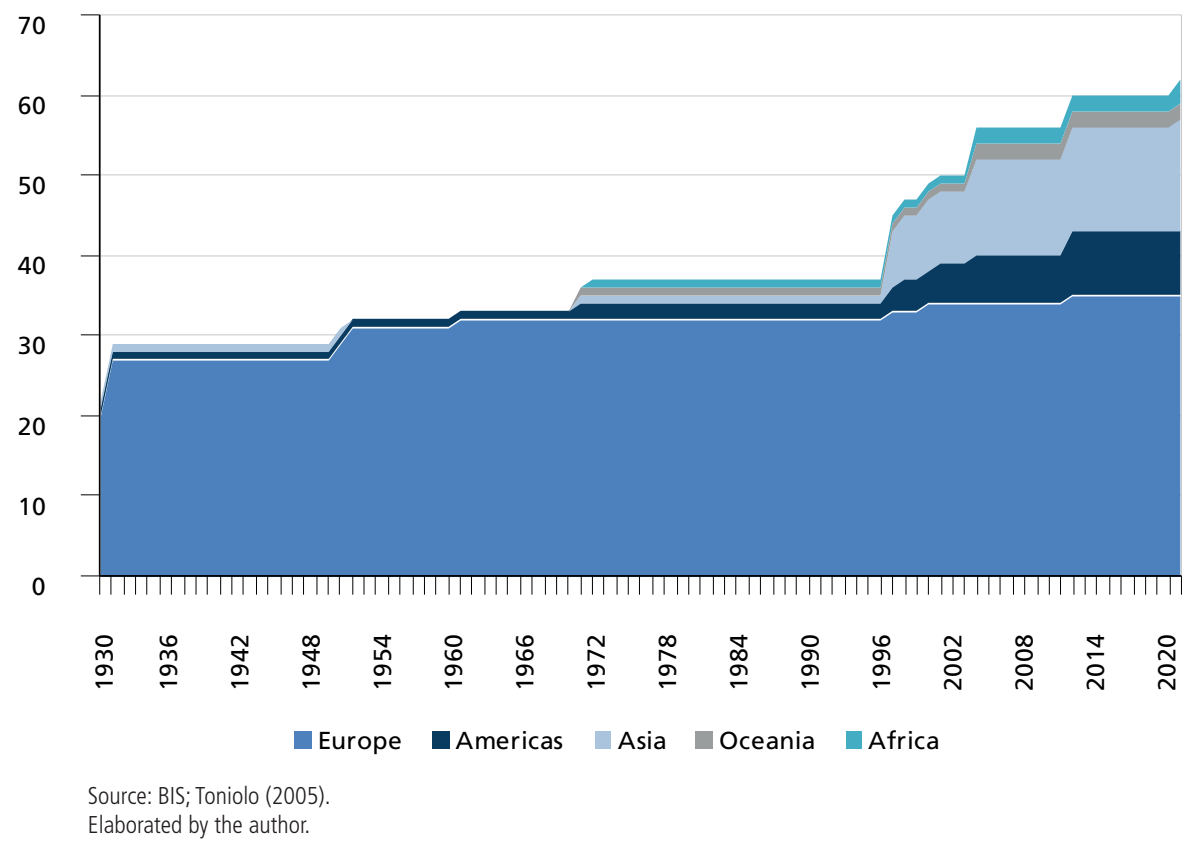

Shortly before the inclusion of emerging-market economies in 1996, American participation in the BIS was finally formalized. Although it had been entitled to two BIS Board seats since 1930, the Fed chose not to exercise that prerogative for more than six decades. The success of European integration and the consequent BIS expansion plans precipitated the decision in 1994, as Fed chairman Alan Greenspan explained to his fellow Fed colleagues:

our relationship with the BIS seemed to be appropriately constrained to our periodic visits over there to deal with the G10 on a consultative basis (...). With the advent of the Maastricht Treaty and the development of the European Monetary Institute, the potential of the BIS being effectively neutered, because of the overlap in jurisdictions of the EMI and the BIS, has led the BIS to move toward a much more global role, one that anticipates inviting a significant number 
of non-European members (...). That would significantly alter its character from a largely though not exclusively European managed operation to one which is far more global. (...) it would be advisable for us to be involved (...) rather than to stay on the sidelines, as we chose to do through all those decades (...) to make certain that we as the principal international financial player have a significant amount to say in the evolution of the institution. ${ }^{32}$

There have been four rounds of BIS enlargement since the admission of emerging-market central banks in 1996. Three years later, four new members were added: the ECB and the central banks of Argentina, Thailand and Malaysia. Six central banks became BIS shareholders in 2003: Algeria, New Zealand, Philippines, Chile, Indonesia and Israel. Four admissions took place in 2011 Luxembourg, Peru, Colombia and the United Arab Emirates. Finally, in 2020, the institution took on its two newest members, Kuwait and Morocco. ${ }^{33}$ The broadening of the bank's geographic reach was also demonstrated by the inauguration of two representative offices: for Asia and the Pacific, in 1998, and for the Americas, in 2002. Located in Hong Kong and Mexico City, those offices serve as focal points for cooperation between BIS member central banks in their respective regions.

In the last twenty-five years, the BIS welcomed twenty-five new members, but that significant expansion was also highly selective. Although its global reach is undeniable, the BIS remains far from universal. Europe's weight is still anachronistically disproportionate. While virtually all European countries are part of the BIS - thirty-five of its sixty-two members - there are only six Latin Americans and three Africans. It should also be noted that the inclusion of new members does not translate immediately or automatically into more democratic governance. There are, nevertheless, recent signs of progress in that direction.

\section{GOVERNANCE AND POWER STRUCTURE IN THE BIS}

Three percent exceeds 2 percent by 50 percent, not by 1 percent.

Edward Denison

Voting power in BIS General Meetings is proportional to the number of shares subscribed in each member jurisdiction. However, the BIS does not disclose its shareholding structure, probably because it is the most outdated feature of its governance. The founding members initially subscribed to most shares, and the BIS statutes ensured that their voting power was not diluted even as other

32. Available at: <https://www.federalreserve.gov/monetarypolicy/files/FOMC19940720confcall.pdf\#page=11>.

33. Vietnam's central bank was also invited to subscribe to BIS shares in January 2020, alongside those of Kuwait and Morocco, but until June 2020 had not taken up the offer. 
members joined. ${ }^{34}$ The last time the BIS released an official list with the number of shares owned by each member was back in the 1930s (BIS, 1939, annex I).

Since then, there have been many changes in the institution's shareholding structure. When Japan was expelled in 1951, the European central banks represented on the Board repurchased its shares. ${ }^{35}$ New members joined between 1950 and 1960, but no new shares were issued, and reports released by the BIS do not explain if and how its shares were redistributed. In the 1970s, the bank increased its capital to allow the admission of new shareholders, but its reports only reveal the total number of shares issued, without detailing how many went to each member. See the following cryptic excerpt in which the BIS (1970, p. 184) describes the issue of 48,325 new shares on the occasion of Canada's entry and Japan's readmission:

as a result of this issue the central banks of Canada and Japan (...) became members of the Bank. At the same time, two other central banks which were already members of the Bank subscribed for additional shares in order to round off the number of shares which they had previously subscribed when joining the Bank. In addition, the new provisions of Article 9 of the Statutes were applied for the first time, and the founder central banks which exercised their rights under Article 8(2) to subscribe for a proportion of the newly-issued shares placed some of these shares at the disposal of the Bank for cancellation. As a result, the Board of Directors was able to issue an equivalent number of fresh shares to other member central banks.

Based on the BIS reports only, it would have been impossible to determine its shareholding structure. Information scattered on central banks' websites was helpful, but it can be misleading. Some members describe their participation in the BIS only as a percentage of the total capital. Other central banks present the number of shares they hold but do not specify how many of those carry voting rights. Others do not disclose any information at all. BIS documents on the compulsory repurchase of shares from private investors in 2001 also helped complement the picture. The final puzzle pieces were assembled thanks to publications by two "official historians" of the BIS: Toniolo (2005) and Schenk (2020). ${ }^{36}$ The result of this thorough investigation can be seen in Figure 2, which lays out the voting power of each central bank at BIS General Meetings, and in Table 1, which can be found in the end of this text and reveals the number of voting shares each member holds, as well as the sources used.

\footnotetext{
34. BIS statutes provide, in article 8, that whenever new shares are issued, the central banks of Belgium, France, Germany, Italy, the United Kingdom and the United States have the right to subscribe in equal parts to at least $55 \%$ of the new capital (BIS, 2019a, p. 9).

35. "Extract of the minutes of the meeting of the Board of Directors of the BIS", BIS Archives, no 7.6, 9 July 1951. 36. Borio et al. (2020, p. 240) explain that the BIS applies a thirty-year access restriction to its archives for "external researchers", but Schenk and others were given access to more recent material, "on the condition that they respected certain confidentiality limitations", in order to write chapters for a book celebrating the institution's 90 th anniversary. Toniolo (2005) had the same special access for his book marking the bank's $75^{\text {th }}$ birthday. The BIS thus creates its own "official history" and attempts to control the narrative and interpretation of its past activities.
} 
The Quiet Central Bank Diplomacy at the Bank for International Settlements (BIS): who gets voice and vote?

FIGURE 2

Voting power of shareholder central banks at BIS General Meetings (June 2020)

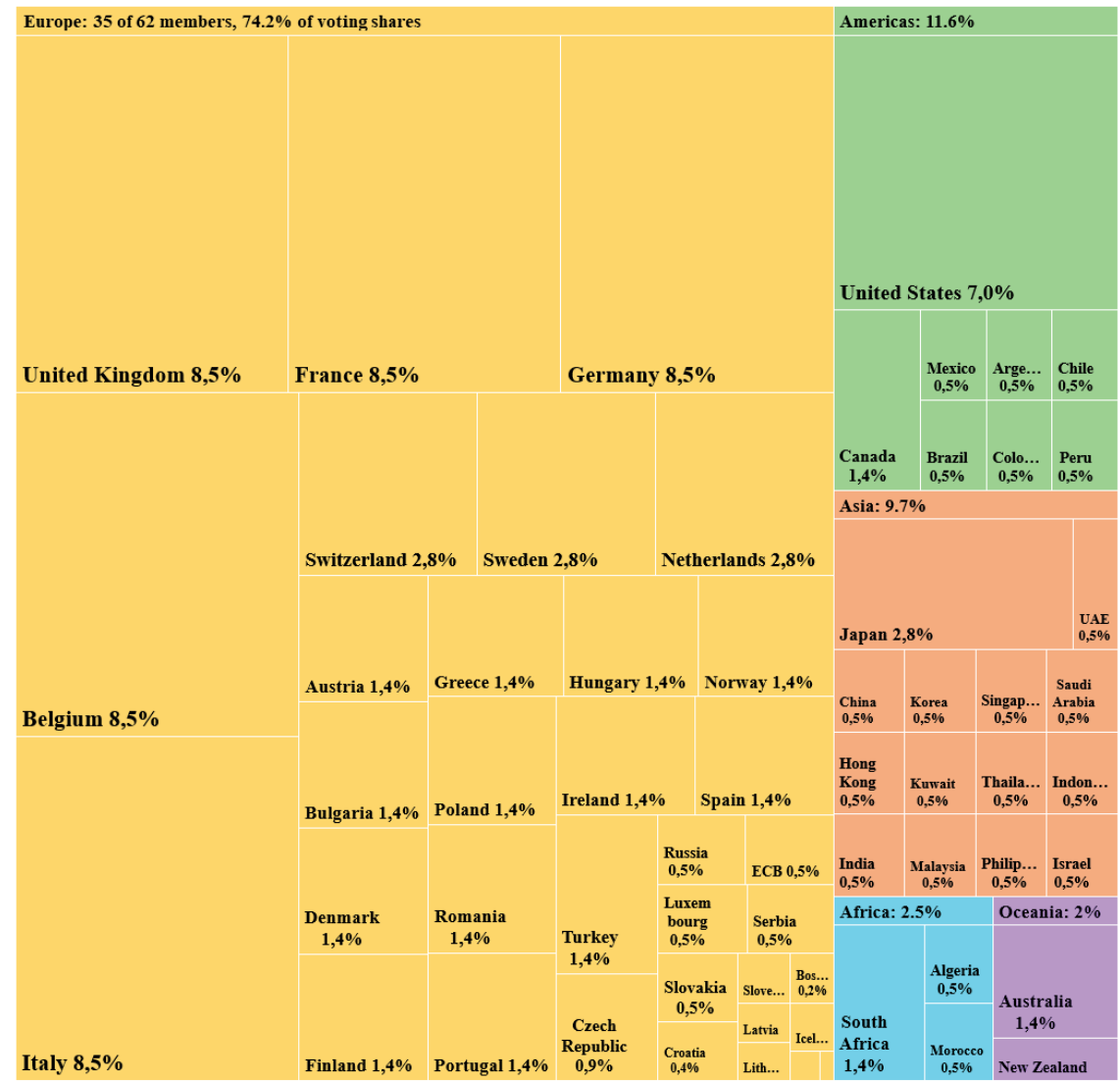

Source: BIS; central banks; Toniolo (2005); Schenk (2020)

Elaborated by the author.

European central banks are the real owners of the BIS, controlling almost three-quarters of its voting capital. Members who joined earlier usually hold more shares. The founding members control $49 \%$ of the voting power. Germany, Belgium, France, Italy and the United Kingdom hold 47,677 voting shares each, or $8.5 \%$ of the total. The voting power of the United States is just 7\%, lower than that of the Europeans. That is because the Fed did not exercise, for decades, its rights as a founding member. ${ }^{37}$ The Netherlands, Sweden and Switzerland,

37. In the case of the United States, BIS shares were subscribed in 1930 by a group of three banks: J. P. Morgan, First National Bank of Chicago and First National Bank of New York. The latter exercised United States voting rights at BIS general meetings ("Letter from Maurice Frère to Allan Sproul", BIS Archives, no 7.6, 4 Apr. 1955). This situation was provided for in Article 15 of the statutes: "should the central bank of any country not desire to exercise these rights, they may be exercised by a financial institution of widely recognised standing and of the same nationality, appointed by the Board, and not objected to by the central bank of the country in question" (Toniolo, 2005, p. 637). 
Board members since 1931, hold 16,000 shares each, or almost $3 \%$ of the votes. The archaic G10, composed of the countries just mentioned in addition to Canada and Japan, controls almost two-thirds of the votes.

Central banks that joined the BIS since the 1990s were each offered 3,000 shares, which currently represent $0.53 \%$ of the capital. That is the voting power of Brazil, Russia, India and China. South Africa, a BRICS member that joined the Basel institution earlier, has considerably more: 8,000 shares, or $1.4 \%$ of the total. Brazil's voting power at BIS General Meetings is much lower than its participation in the IMF, increased in 2016 to $2.32 \%$ of the shares and $2.22 \%$ of the voting power (BCB, 2017, p. 39). Comparing the voting power of European countries in both international financial institutions shows their predominance to be even more pronounced in the BIS. Belgium has $550 \%$ more voting power in the Basel institution than in the IMF. In the case of the other European BIS founders, that comparison generates the following results: Italy, + 180\%; France and the United Kingdom, + 110\%; Germany, + 59\%. ${ }^{38}$

With regard to its shareholding structure, the BIS can be criticized both for lack of transparency and for anomalies in the distribution of capital, which is partially determined by decisions made in 1930. But the relevance of voting power at BIS General Meetings should not be overstated. Besides the crucial prerogative of approving amendments to the statutes, used only thirteen times during the organization's nine-decade trajectory, General Meetings have relatively limited and bureaucratic tasks, such as determining the distribution of profits; approving the annual report and the BIS accounts; adjusting the remuneration paid to Board members; and selecting the bank's independent auditor. General Meetings are also only one of three levels of BIS governance. In the other two, namely the Board of Directors and Management, there have been notable changes in recent years.

The Board of Directors, responsible for determining the institution's strategic direction and supervising BIS Management, meets at least six times a year. Governors of the BIS founding central banks are ex officio Board directors. Until 2018, each of these had the right to appoint another national of their own country as an additional director, which meant two Board seats for each BIS founder. Other governors of BIS member central banks may also be elected as directors. Europeans have always dominated the Board. In the 1930s, Japanese officials and American private bankers served as directors, but after the war, with the exclusion of Japan and with the Fed's lack of interest in the BIS, the Board became exclusively European. The five European founders had two seats each, and there were three "elected" directors, who were invariably the central bankers of the Netherlands, Switzerland and Sweden (BIS, 1980, p. 66-67).

38. At the BIS, the voting power of each European founder is $8.45 \%$. At the IMF, it is as follows: Belgium, 1.3\%; Italy, 3.02\%; France, 4,03\%; United Kingdom, 4.03\%; Germany, 5.32\%. Available at: <https://bit.ly/2BbNNEU>. 
In 1994, when the United States finally decided to take up its two seats on the Board, the central bankers of Japan and Canada were also included. The number of board directors grew to seventeen, of which thirteen were European. These were not radical changes, as they merely completed the incorporation to the BIS Board of all G10 central bank governors, a group that had been meeting informally in Basel since the 1960s.

Emerging-market economies first became BIS members in 1996 but were not admitted to the Board until ten years later, when the central bank governors of China and Mexico - as well as the ECB president - were elected as directors. The BIS (2007, p. 157) explained that the decision was "in line with the Bank's more global role. (...) Following the increase in the number of BIS shareholders in recent years, these elections bring the global diversity of BIS membership to Board level". The ECB president occupied one of the ten seats to which the five European founders were entitled, ${ }^{39}$ so the number of Europeans on the Board did not increase. The number of Board members went up from seventeen to nineteen.

In 2010, Henrique Meirelles, elected to replace Guillermo Ortiz, whose term at the head of Banxico had ended, became the first Brazilian to join the BIS Board. When Meirelles left his job at the end of 2010, he was replaced on the BIS Board by another Mexican, Agustín Carstens. In 2013, the number of emerging-market Board members doubled to four. In addition to China and Mexico, the central bank governors of Brazil (Alexandre Tombini) and India were elected. Since then, the participation of these four countries on the Board has been maintained. In the case of Brazil, after Tombini left his post, his successors, Ilan Goldfajn and Roberto Campos Neto, were successively elected to join the Board.

The most radical change in the Board composition, decided at an Extraordinary General Meeting held in 2016 and implemented in 2019, was the reform of article 27 of the BIS statutes, which previously gave each founding member two seats on the Board. The new wording provides that the six ex officio Board members central bank governors of Belgium, France, Germany, Italy, the United Kingdom and the United States - may jointly designate only one additional member, from one of the six nationalities. In practice, the additional member of the Board will probably always be an American. European founders now have just one seat each, while the United States continues to occupy its traditional two seats - one for the Fed chairman in Washington and one for the New York Fed president.

Jens Weidmann, Bundesbank president and BIS Board chairman, stated that "changing Article 27 is a historic achievement for the BIS. It will significantly

39. This arrangement was not explicitly described by the BIS, but it is possible to infer, from lists of Board members published in BIS annual reports, that European founders started to give up one seat, on a rotating basis, to make room on the Board for the ECB. Schenk (2020, p. 80) confirms the arrangement: "the directors from the five European founder central banks agreed to take turns for one of their second directors to come off the Board each year to make way for the ECB president". 
improve the balance between the different world regions represented on the Board" (BIS, 2017). Some changes, however, went in the opposite direction. Even though the six founding central banks no longer have a majority in the Board, they kept their veto power on decisions such as inviting new members, issuing shares and changing the statutes. For these issues, in addition to two-thirds of the Board votes, the new rules require the consent of a majority of the ex officio members. That means that their votes now have more weight than those of others. ${ }^{40}$

The new wording of Article 27 resulted in four Europeans leaving the Board. Three of those seats were eliminated, and the maximum number of Board members was reduced from 21 to 18 . For the remaining vacancy, the South Korean central bank governor was elected, and the number of emerging-market directors rose to five. Figure 3 shows the described changes in BIS Board composition. There has been a significant renewal in the past twenty-five years. Europeans, who had all Board seats until 1994, now control "only" half of them, or nine out of eighteen. It is some progress, but not enough. The Board still includes governors of five national eurozone central banks, whose primary tasks, such as issuing currency and conducting monetary policy, were delegated over two decades ago to the ECB, which is also on the Board.

FIGURE 3

Evolution of the composition of the BIS Board of Directors

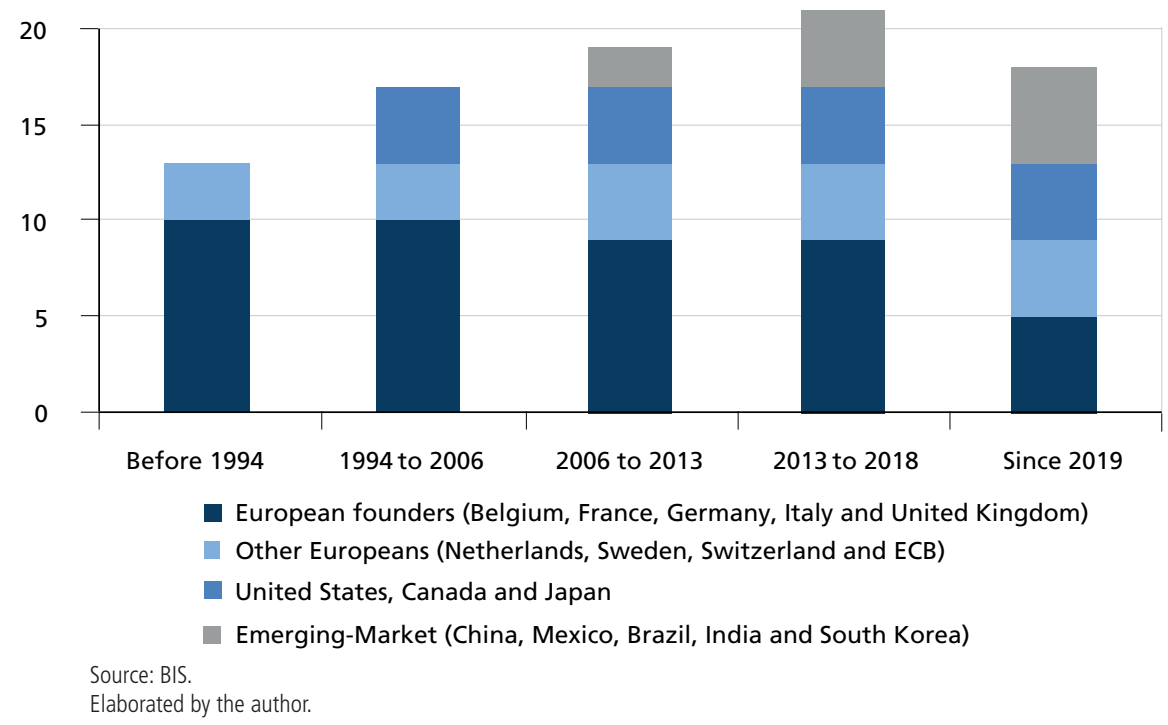

Ideally, just as the United States has two members on the Board, the eurozone should have only the ECB president and one national central banker. Europeans

40. See Article 27 (5) of the BIS statutes (BIS, 2019a, p. 18). 
would lose four extra seats, and the Board would have fourteen members, a similar size to the one it had before 1994, with a balanced composition between three groups: five seats for Europeans; four seats for other advanced countries - Canada, Japan and the United States; and five seats for emerging-market economies. As sensible as that configuration may seem, Europeans will probably resist giving up more Board seats in the short term. Interviewed by the author in 2017, Jaime Caruana, then BIS general manager, minimized the importance of voting power in the Board of Directors and at General Meetings, arguing that the BIS usually operates by consensus. Nevertheless, the kind of consensus reached in a mostly European environment tends to be different from the one that would be achieved in a more diverse group.

Efforts of renewal in Basel have also reached the BIS Management, which is the third level of the bank's governance. For decades, the top positions in Management were reserved for certain nationalities. Until recently, the so-called Executive Committee ${ }^{41}$ consisted only of natives of Europe or North America. That pattern was first broken in 2014 when the Korean Hyun Song Shin was appointed economic adviser and head of research.

The opening up of BIS Management to emerging-market countries moved ahead the following year with the election of a Brazilian, then central bank director Luiz Awazu Pereira da Silva, as deputy general manager. The speedy process culminated in 2016 when Mexican central banker Agustín Carstens was elected BIS general manager. The presence at the top of the hierarchy of nationals of Mexico and Brazil, classified in 1983 by the then BIS general manager as "major problem countries", ${ }^{42}$ represents, at least in symbolic terms, a marked break with the tradition of the Basel institution, historically controlled by developed countries. It is also a radical departure from the standard practice in international organizations - still in force at the IMF and the World Bank - of reserving the top jobs for specific countries or regions.

The distribution of power in the formal decision-making bodies of the BIS - General Meetings, Board of Directors and Management - is paralleled in the formats of central bankers' meetings held on a bimonthly basis. As mentioned earlier, these somewhat informal and private gatherings facilitate the exchange of relevant information about the global economy and are at the heart of central bank cooperation in Basel. But not all members have access to every meeting. The BIS is like a hierarchical club, and some members have more perks than others.

The most exclusive group is the Economic Consultative Committee (ECC), made up of the Board members and the general manager. On the BIS tower's top

41. Executive Committee members are chosen by the Board and include the BIS general manager, the deputy general manager and the heads of departments - see Article 41 of the statutes (BIS, 2019a, p. 22).

42. "Letter from Günther Schleiminger to Jacques de Larosière", BIS Archives, no 1.26C, 9 June 1983, p. 2. 
floor, the group enjoys refined dinners in which the free discussion of economic topics is accompanied by carefully selected wines. The ECC makes proposals for the consideration of a larger group, the Global Economy Meeting (GEM), which includes thirty central bank governors of economies that together represent $80 \%$ of world gross domestic product (GDP). Nineteen other central bankers take part as observers. BIS researchers suggest themes to be addressed at each meeting and prepare studies to support the discussions. Finally, the All Governors' Meeting includes all BIS members. Figure 4 summarizes the elaborate scheme by which the BIS is able to promote broad participation in bimonthly meetings without giving up the limited character of the inner circle. While there is a significant emerging-market representation at the GEM, the same historical idiosyncrasies that affect the BIS Board composition determine access to the restricted ECC meetings. The involvement of small European countries in the issue of war reparations in 1929 guarantees their access, in 2020, to the Basel club's most exclusive gatherings, in which two-thirds of the participants are members of the good old G10.

FIGURE 4

Concentric circles of central bank groupings at the BIS

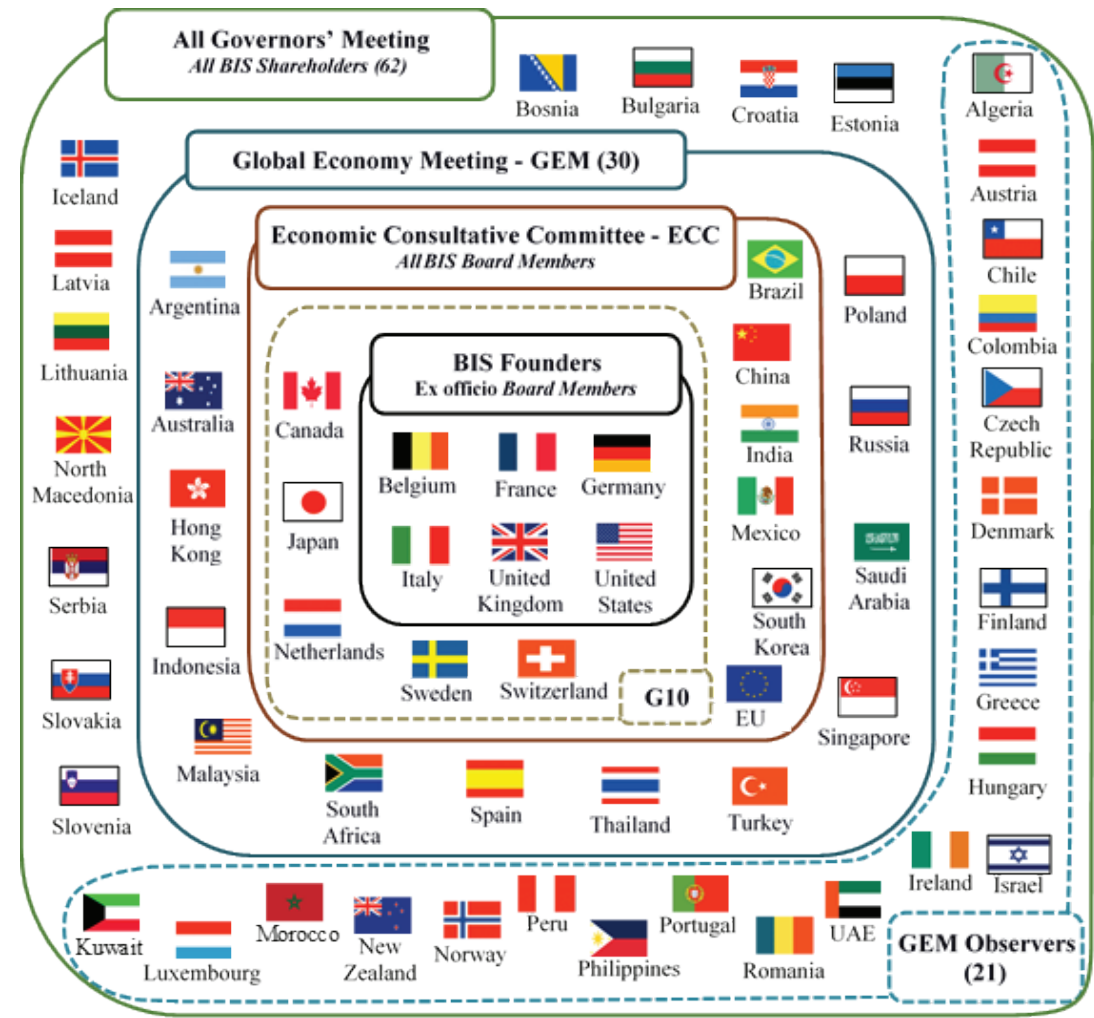

Source: BIS.

Elaborated by the author. 


\section{BRAZIL IN THE BANK FOR INTERNATIONAL SETTLEMENTS}

What this dangerous tendency, to regard Brazil as an exceptionally favoured community to which ordinary rules do not apply, very clearly indicates is that Political Economy is either very little understood in this country, or that it is not regarded even by the most advanced thinkers as an exact science.

Joseph Phillip Wileman, 1896

On September 9, 1996, the BIS Board decided to invite nine central banks from emerging countries, including Brazil, to subscribe to the institution's shares (BIS, 1997b, p. 183). Since it involved spending public money, the issue had to be submitted to the Brazilian congress, but there was no debate about the convenience or the implications of joining the BIS. For several months, the matter stayed dormant as an extra item on the agenda of the chamber of deputies' foreign affairs committee. In March 1997, with the approach of the deadline established by the BIS for the subscription of shares, an expedited legislative procedure was suddenly adopted, the required bill was fast-tracked through both houses of parliament, ${ }^{43}$ and Brazil's central bank paid over thirty-five million dollars for its three thousand BIS shares (BCB, 1998, p. 153 and 191).

Brazil's central bank effusively celebrated the new membership, saying that, until then, "no Latin American central bank had been accorded the privilege of adhering to BIS" (BCB, 1997, p. 162). That enthusiasm is understandable, considering that Brazil wanted to join the organization since the 1970s. Unlike the United States, which had effectively snubbed the BIS for more than six decades, Brazil could not afford to stay out of a relevant forum of multilateral consultation. As in other areas of global governance, Brazil has an interest in reinforcing the role of institutions that allow the country to participate in the discussion of issues that would otherwise be subject to unilateral decisions. Brazil's process of admission was characterized by undesirable inertia, without any debate in congress or society, but that is not surprising. The BIS manages to keep out of political controversy and to avoid the media spotlight by conveying the impression that its tasks are purely technical and of little interest to ordinary citizens.

Decisions made in Basel have a direct impact on the activities of central banks and, therefore, on the lives of people around the globe. That is particularly visible in the area of banking regulation. BIS-based committees and associations, each responsible for a different aspect of global monetary and financial stability, generate multiple standards, principles, best practices, recommendations 
and guidelines. These non-binding rules are commonly classified as "soft law" and tend to be widely adopted, even by countries that do not participate in their elaboration.

The global adoption of these regulatory standards - the most notable of which are the successive versions of the Basel accords - can be attributed to peer pressure mechanisms and market incentives. The pressure for strict implementation can be particularly intense for developing countries that, needing access to external resources, have to prove the credibility of their policies and institutions. Compliance with Basel standards is also used as a parameter in periodic assessments carried out by the IMF and the World Bank on the state of public policies and financial systems in different countries.

Implementation of Basel rules in Brazil began in 1994, with the establishment of a minimum capital requirement for banks, and gained momentum with the country's admission to the BIS. In a public hearing in 2001, former governor Gustavo Franco confirmed that, after 1997, Brazilian central bank directors started attending Basel meetings regularly; officials in charge of banking supervision received training at the BIS and went through "very intense learning"; and many new rules were issued by the central bank, reflecting, in particular, the so-called Basel Core Principles. ${ }^{44}$

Participation in BIS committees and associations, such as the Basel Committee on Banking Supervision, was traditionally limited to a few developed countries. Several groups reported to the G10 central bankers, who had been meeting in Basel since the 1960s. Since the global financial crisis, however, the debate on financial regulation became more visible and politicized, and these forums were compelled to become more inclusive. As a result of G20 negotiations, Brazil and other large emerging-market economies got seats in several BIS committees starting in 2009. Nowadays, Brazil's central bank has the opportunity to participate in discussions and influence decisions in Basel, even if, due to the scarcity of human and financial resources, it has to prioritize specific topics and meetings to the detriment of others considered less relevant to the country's interests.

Current relations between Brazil and the BIS are intense and multifaceted, going far beyond the negotiation and implementation of regulatory standards. Cooperation with the BIS includes the compilation of statistics, reserve management, economic research and staff training. As noted earlier, Brazil became involved in BIS governance, with successive Brazilian central bank governors serving as BIS Board directors, starting in 2010; and with the choice 
of a Brazilian national as BIS deputy general manager, in 2015. A search for official gazette publications in the twelve months between December 2017 and November 2018 revealed no less than 193 authorizations for Brazilian central bank officials to travel abroad to participate in activities promoted by the BIS and its related groups. Besides the bimonthly meetings of central bank governors, those events included conferences, seminars and meetings of the various committees linked to the BIS, held not only in Basel but also in forty-two other cities around the globe. In a laudatory editorial published in December 2018, Brazilian newspaper Estadão wrote: "created more than half a century ago, in few moments the Central Bank of Brazil resembled as much as it does today similar institutions in more advanced countries". ${ }^{45}$ That can be attributed, in no small measure, to the relationship with the BIS.

\section{THE CHALLENGES AHEAD}

It is really true what philosophy tells us, that life must be understood backwards. But with this, one forgets the second proposition, that it must be lived forwards.

Søren Kierkegaard

The BIS cherishes its low profile, but has recently become a global organization. It brings together sixty-two central banks from countries that account for 95\% of global GDP. In its expansion process, the world's oldest international financial institution seems to seek a balance between, on the one hand, the imperative to become more inclusive and diverse to keep its relevance and, on the other, the desire to protect the traditional character of an exclusive and like-minded club. In an institution controlled for decades by the G10, the inclusion of emerging-market central banks has been a slow and careful process, to avoid going too far.

Despite the crucial steps the BIS has recently taken to renew its decision-making bodies, further changes are needed. The institution's governance remains partially conditioned by the late 1920s' geopolitical context, particularly concerning the excessive European weight in the Board of Directors and in the shareholding structure. To maintain its relevance, the BIS must promote additional reforms in terms of representativeness, legitimacy of its processes and transparency.

Moreover, the institution faces at least two major sets of challenges on the road ahead. First, the BIS and its members need to keep up with the constant flow of technological innovation in the financial sector, such as the rise of fintech and the emergence of crypto-assets. Secondly, the Covid-19 pandemic will leave behind a vast and lasting impact on global financial systems and monetary

45. "O Pacote de Segurança do BC", 0 Estado de São Paulo, 6 December 2018 (translation by the author). 
markets, not to mention its implications for the way the BIS works. On its 90th anniversary, in May 2020, BIS meetings were being held virtually due to the social distancing measures aimed at containing the spread of coronavirus. It remains to be seen whether its traditional model of central bank cooperation, heavily reliant on air travel and frequent face-to-face interactions in Basel, will remain feasible.

Brazil's central bank would do well to maintain its firm engagement with the BIS and help it face these challenges. As a forum for coordination and consultation, the BIS plays an essential role in global financial governance. Countries with leaders from opposite poles of the political spectrum have been working together in Basel for decades, although not always successfully, for the common good represented by monetary and financial stability. In times when, as in the 1930s, threats of economic disintegration arise, fueled by nationalism and protectionism, an institution like the BIS, which provides a venue for dialogue and a system of jointly agreed rules, deserves to be upheld and strengthened.

TABLE 1

Dates of membership, shareholding structure and voting power at BIS General Meetings

\begin{tabular}{|c|c|c|c|}
\hline Central Bank & Date of membership ${ }^{1}$ & Voting shares & Voting power (\%) \\
\hline Belgium & 20 May 1930 & $47,677^{2}$ & 8.45 \\
\hline France & 20 May 1930 & $47,677^{3}$ & 8.45 \\
\hline Germany & 20 May 1930 & $47,677^{4}$ & 8.45 \\
\hline Italy & 20 May 1930 & $47,677^{5}$ & 8.45 \\
\hline United Kingdom & 20 May 1930 & 47,677 & 8.45 \\
\hline United States ${ }^{6}$ & 20 May 1930 & 39,540 & 7.01 \\
\hline Netherlands & 20 May 1930 & $16,000^{7}$ & 2.84 \\
\hline Sweden & 20 May 1930 & 16,000 & 2.84 \\
\hline Switzerland & 20 May 1930 & 16,000 & 2.84 \\
\hline Austria & 25 June 1930 & $8,000^{8}$ & 1.42 \\
\hline Bulgaria & 25 June 1930 & 8,000 & 1.42 \\
\hline Denmark & 25 June 1930 & 8,000 & 1.42 \\
\hline Finland & 25 June 1930 & 8,000 & 1.42 \\
\hline Greece & 25 June 1930 & 8,000 & 1.42 \\
\hline Hungary & 25 June 1930 & 8,000 & 1.42 \\
\hline Poland & 25 June 1930 & 8,000 & 1.42 \\
\hline Romania & 25 June 1930 & 8,000 & 1.42 \\
\hline Czech Republic & 25 June $1930^{9}$ & 5,330 & 0.94 \\
\hline Slovakia & 25 June 1930 & 2,670 & 0.47 \\
\hline Estonia & 31 October 1930 & $200^{10}$ & 0.04 \\
\hline Latvia & 30 December 1930 & 1,000 & 0.18 \\
\hline
\end{tabular}


The Quiet Central Bank Diplomacy at the Bank for International Settlements (BIS): who gets voice and vote?

(Cont.)

\begin{tabular}{|c|c|c|c|}
\hline Central Bank & Date of membership ${ }^{1}$ & Voting shares & Voting power (\%) \\
\hline Lithuania & 31 March 1931 & 1,000 & 0.18 \\
\hline Norway & 30 May 1931 & $8,000^{11}$ & 1.42 \\
\hline Bosnia & 28 June 1931 & $1,056^{12}$ & 0.19 \\
\hline Croatia & 28 June 1931 & 2,280 & 0.40 \\
\hline North Macedonia & 28 June 1931 & 432 & 0.08 \\
\hline Serbia & 28 June 1931 & 2,920 & 0.52 \\
\hline Slovenia & 28 June 1931 & 1,312 & 0.23 \\
\hline Iceland & 28 November 1950 & $1,000^{13}$ & 0.18 \\
\hline Ireland & 5 December 1950 & 8,000 & 1.42 \\
\hline Portugal & 10 January 1951 & 8,000 & 1.42 \\
\hline Turkey & 24 May 1951 & 8,000 & 1.42 \\
\hline Spain & 28 December 1960 & 8,000 & 1.42 \\
\hline Canada & 2 January 1970 & 8,000 & 1.42 \\
\hline Japan & 2 January $1970^{14}$ & 16,000 & 2.84 \\
\hline Australia & 31 December 1970 & $8,000^{15}$ & 1.42 \\
\hline South Africa & 30 June 1971 & 8,000 & 1.42 \\
\hline China & 1 November 1996 & $3,000^{16}$ & 0.53 \\
\hline Hong Kong & 1 November 1996 & 3,000 & 0.53 \\
\hline India & 1 November 1996 & 3,000 & 0.53 \\
\hline Mexico & 1 November 1996 & 3,000 & 0.53 \\
\hline Russia & 1 November 1996 & 3,000 & 0.53 \\
\hline Saudi Arabia & 1 November 1996 & 3,000 & 0.53 \\
\hline Singapore & 1 November 1996 & 3,000 & 0.53 \\
\hline South Korea & 14 January 1997 & 3,000 & 0.53 \\
\hline Brazil & 25 March 1997 & 3,000 & 0.53 \\
\hline European Central Bank & 9 December 1999 & $3,000^{17}$ & 0.53 \\
\hline Malaysia & 24 December 1999 & 3,000 & 0.53 \\
\hline Thailand & 1 March 2000 & 3,000 & 0.53 \\
\hline Argentina & 28 March 2000 & 3,000 & 0.53 \\
\hline Algeria & 28 July 2003 & $3,000^{18}$ & 0.53 \\
\hline New Zealand & 15 August 2003 & 3,000 & 0.53 \\
\hline Philippines & 18 September 2003 & 3,000 & 0.53 \\
\hline Chile & 26 September 2003 & 3,000 & 0.53 \\
\hline Indonesia & 29 September 2003 & 3,000 & 0.53 \\
\hline Israel & 30 September 2003 & 3,000 & 0.53 \\
\hline Luxembourg & July 2011 & $3,000^{19}$ & 0.53 \\
\hline Peru & July 2011 & 3,000 & 0.53 \\
\hline
\end{tabular}


(Cont.)

\begin{tabular}{|c|c|c|c|}
\hline Central Bank & Date of membership ${ }^{1}$ & Voting shares & Voting power (\%) \\
\hline Colombia & December 2011 & 3,000 & 0.53 \\
\hline United Arab Emirates & December 2011 & 3,000 & 0.53 \\
\hline Kuwait & February 2020 & $3,000^{20}$ & 0.53 \\
\hline Morocco & February 2020 & 3,000 & 0.53 \\
\hline
\end{tabular}

Elaborated by the author.

Notes: ${ }^{1}$ The membership dates, obtained in BIS annual reports and in the chronology presented by Toniolo (2005, p. 667-696), refer to the moment when the BIS shares were initially subscribed by each central bank

${ }^{2}$ Available at: <https://bit.ly/2C5NkV5>. Belgium also has 2,423 non-voting shares bought in 2005. Available at: $<$ https://bit.ly/3cZQUgn>.

${ }^{3}$ In 2017, the Banque de France reported owning $8.96 \%$ of the BIS capital (available at: <https://bit.ly/37iS85b>), or almost 50,100 shares, the same amount held by Germany and Belgium, including their non-voting shares.

${ }^{4}$ Available at: <https://bit.ly/3fjVKXe>. Germany also has 2,423 non-voting shares bought in 2005. Available at: $<$ https://bit.ly/37taRLg>.

${ }^{5}$ In 1998, the Banca d'Italia reported having 49,114 shares, but that certainly includes non-voting shares. Available at: <https://bit.ly/30EVFCO $>$. The Bank of England reports owning $8.5 \%$ of the BIS capital. Available at: $<$ https://bit. ly/3e2NVF5>.

${ }^{6}$ The case of the Fed is quite peculiar. It is the only member that has never acquired and still does not hold any BIS shares. A group of American private banks subscribed to 19,770 shares between 1930 and 1932, as did the other founding members (available at: <https://bit.ly/3dOuMSN $>$ ). These shares were doubled in 1969 (available at: $<$ https://bit.ly/2BJI2j1>). The Fed finally formalized its BIS membership in 1994, but its shares remained in the hands of private investors until 2001, when they were repurchased by the BIS (2000). The American shares were sold by the BIS to other central banks in 2005, but the Fed still exercises the corresponding voting rights (available at: <https:/l bit.ly/2MBCvfr $>$ and $<$ https://bit.ly/2Y6eyCp $>$ ).

${ }^{7}$ In 1998, Netherlands' central bank reported having $3.11 \%$ of the BIS capital (available at: <https://bit.ly/2MyiCpF>), about 16,000 shares. Sweden's central bank reported having 16,021 shares before buying 1,223 non-voting shares in 2005 (available at: <https://bit.ly/2MyfQRh>). It was supposed that Switzerland should have the same voting power of Sweden and the Netherlands, since the three countries joined the BIS at the same time in 1930, with the same number of shares, and have participated together in the Board of Directors since 1931. That is confirmed by Schenk (2020, p. 64).

8 The central banks of Austria, Bulgaria, Denmark, Finland, Greece, Hungary, Poland and Romania subscribed to 4,000 shares in 1930 (available at: <https://bit.ly/3cF416n>). In 1969, the BIS increased its capital and doubled its original shares, so each central bank now has 8,000 shares (available at: <https://bit.ly/2BJ/2j1>). For Austria, available at: $<$ https://bit.ly/3eYdFT2>, p. 109. Austria also has 564 non-voting shares (available at: $<$ https://bit. ly/2zaAfZz>, p. 106). For Bulgaria, available at: $<$ https://bit.ly/2z9Cs7s>. Romania also has 564 non-voting shares purchased in 2005 (available at: <https://bit.ly/2UkgKVF>, p. 97).

${ }^{9}$ Subscribed in 1930 by Czechoslovakia, the shares were reissued in 1993 and split between the Czech Republic and Slovakia (available at: <https://bit.ly/2UigVRq>). Schenk $(2020$, p. 89) informs how many shares each country got.

${ }^{10}$ Estonia also has fourteen non-voting shares purchased in 2005 (available at: <https://bit.ly/3h3uoGj>, p. 79). The central banks of Latvia and Lithuania subscribed to five hundred shares in 1930 (available at: <https://bit. ly/3cF416n>), doubled in 1969 (available at: <https://bit.ly/2BJ/2j1>). Lithuania also has seventy non-voting shares purchased in 2005 (available at: <https://bit.ly/2Y5S1pa>).

${ }^{11}$ Norway's central bank also has 564 non-voting shares purchased in 2005. Available at: <https://bit.ly/2zeCPOe>

${ }^{12}$ The 8,000 shares subscribed in 1931 by Yugoslavia's central bank were divided in 2001 into the following proportions: Bosnia (13.2\%); Croatia (28.49\%); North Macedonia (5.4\%); Serbia (36.52\%); and Slovenia (16.39\%). Available at: <https://bit.ly/3dGiMXX>. Croatia also has 161 non-voting shares purchased in 2005. Available at: <https://bit. $\mid y / 2 Y 6 e y C p>$.

${ }^{13}$ Iceland's central bank also has seventy non-voting shares purchased in 2005 (available at: $<$ https://bit.ly/2XIUTcR $>$ ). For Ireland, available at: <https://bit.ly/3gYLDsp>. For Portugal, available at: $<$ https://bit.ly/3cGQvzd $>$. For Turkey, available at: $<$ https://bit.ly/3eSA4kA>. It was considered that Spain should have the same number of voting shares as Ireland, Portugal, Turkey and Canada, which joined BIS at around the same time. The Bank of Canada also has 1,441 non-voting shares purchased in 2005 (available at: <https://bit.ly/3dM9k5u>).

${ }^{14}$ Japan was one of the BIS founders in 1930, but in 1951 had to give up its participation as a result of the San Francisco Peace Treaty. The Bank of Japan was readmitted in 1970, when it subscribed to 8,000 shares (Toniolo, 2005, p. 361), and subscribed to another 8,000 shares in 1996 (Schenk, 2020, p. 64).

${ }^{15}$ For Australia's admission, 16,400 new shares were issued. The 1971 BIS annual report informs only that part was allotted to Australia's central bank - it is reasonable to assume 8,000 shares, the same number reserved for new members until then - and the rest was subscribed by different central banks (available at: $<$ https://bit.ly/3f0aAlq $>$ ). The same applies to South Africa's admission the following year (available at: <https://bit.ly/3cK1J5Q>). 
The Quiet Central Bank Diplomacy at the Bank for International Settlements (BIS): who gets voice and vote?

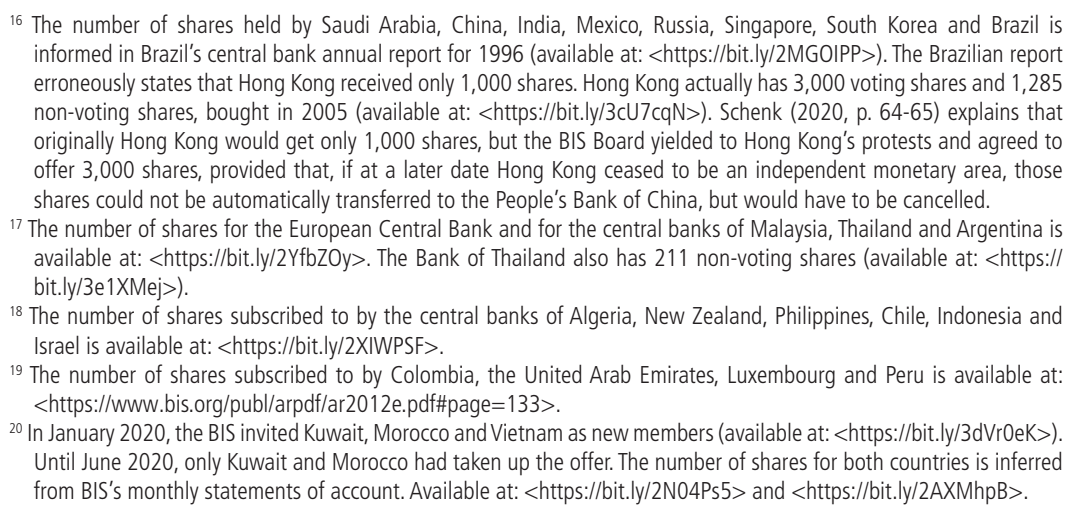

\section{REFERENCES}

ABREU, M. de P. A missão Niemeyer. Revista de Administração de Empresas, v. 14, n. 4, p. 7-28, jul.-ago. 1974. Available at: <https://rae.fgv.br/sites/rae.fgv. br/files/artigos/10.1590_S0034-75901974000400002.pdf>.

BAGEHOT, W. Lombard street: a description of the money market. New York: Scribner; Armstrong, 1873.

BANK OF ENGLAND. Annual report and accounts: 1 March 2018-28 February 2019. London: Bank of England, 2019. Available at: <https://www. bankofengland.co.uk/-/media/boe/files/annual-report/2019/boe-2019.pdf>.

BCB - BANCO CENTRAL DO BRASIL. VI - Organismos financeiros internacionais/international financial institutions. In: Boletim do Banco Central do Brasil: relatório 1996/1996 annual report. Brasília: BCB, Aug. 1997. p. 158-177. Available at: <https://www.bcb.gov.br/pec/boletim/ Banual96/rel96-06.pdf>.

Annual report 1997. Brasília: BCB, Oct. 1998. v. 34. Available at: <https://www.bcb.gov.br/pec/boletim/ingles/banual97/rel97-i.pdf>.

- Relatório da Administração: RA 2016. Brasília: BCB, 2017. Available at: <https://www.bcb.gov.br/Pre/Surel/RelAdmBC/2016/docs/ relatorio_administracao_2016_bcb.pdf>.

BERNANKE, B. S. The courage to act: a memoir of a crisis and its aftermath. New York: W. W. Norton, 2015. 
BIS - BANK FOR INTERNATIONAL SETTLEMENTS. Ninth annual report: 1st April 1938-31st March 1939. Basel: BIS, 8 May 1939. Available at: $<$ http://www.bis.org/publ/arpdf/archive/ar1939_en.pdf>.

Fortieth annual report: 1st April 1969-31st March 1970. Basel: BIS, 8 June 1970. Available at: <http://www.bis.org/publ/arpdf/archive/ar1970_en.pdf>.

Personal recollections and opinions: published on the occasion of the fiftieth anniversary 1930-1980. Basel: BIS, 1980.

Note on gold operations involving the Bank for International Settlements and the German Reichsbank: 1st September 1939 - 9th May 1945. Basel: BIS, 12 May 1997a. Available at: <https://www.bis.org/publ/bisp02b.pdf>.

67th annual report: 1st April 1996-31st March 1997. Basel: BIS, 9 June 1997b. Available at: <https://www.bis.org/publ/ar67f01.pdf>.

. Note to private shareholders: withdrawal of all shares of the Bank for International Settlements held by its private shareholders. Basel: BIS, 15 Sept. 2000. Available at: <https://www.bis.org/about/notesholde.pdf>.

. 77th annual report: 1 April 2006-31 March 2007. Basel: BIS, 24 June 2007. Available at: <https://www.bis.org/publ/arpdf/ar2007e.pdf>.

Changes to BIS statutes regarding board composition. BIS, 25 June 2017. Available at: <https://www.bis.org/press/p170625a.htm>.

Basic texts. Basel: BIS, Jan. 2019a. Available at: <https://www.bis.org/ about/basictexts-en.pdf>.

. Annual report 2018/19. Basel: BIS, June 2019b. Available at: <https:// www.bis.org/about/areport/areport2019.pdf>.

BLUSTEIN, P. The chastening: inside the crisis that rocked the global financial system and humbled the IMF. New York: Public Affairs, 2001.

BORDO, M. D.; SCHENK, C. Monetary policy cooperation and coordination: an historical perspective on the importance of rules. In: BORDO, M. D.; TAYLOR, J. B. (Ed.). Rules for international monetary stability: past, present, and future. Stanford: Hoover Institution Press, 2017. p. 205-261. Available at: $<$ https:/www.hoover.org/sites/default/files/research/docs/rulesforinternationalm onetarystability-ch5_0.pdf>.

BORIO, C. et al. (Ed.). Promoting global monetary and financial stability: the Bank for International Settlements after Bretton Woods, 1973-2020. Cambridge: Cambridge University Press, 2020. 
BRASIL. Diário da Câmara dos Deputados. Brasília: Câmara dos Deputados, 6 Mar. 1997a. Available at: <http://imagem.camara.gov.br/Imagem/d/pdf/ DCD06MAR1997.pdf>.

Diário da Câmara dos Deputados. Brasília: Câmara dos Deputados, 7 Mar. 1997b. Available at: <http://imagem.camara.gov.br/Imagem/d/pdf/ DCD07MAR1997.pdf>.

Diário do Senado Federal. Brasília: Senado Federal, 11 Mar. 1997c. Available at: <http://legis.senado.leg.br/diarios/BuscaDiario?anoDiario=52\&nu $\mathrm{mDiario}=38$ \& tipDiario $=1 \#>$.

Diário do Senado Federal. Brasília: Senado Federal, 19 Mar. 1997d. Available at: <http://legis.senado.leg.br/diarios/BuscaDiario?anoDiario=52\&nu $\mathrm{mDiario}=44 \&$ tipDiario $=1 \#>$.

Diário do Senado Federal. Brasília: Senado Federal, 20 Mar. 1997e. Available at: <http://legis.senado.leg.br/diarios/BuscaDiario?anoDiario=52\&nu $\mathrm{mDiario}=45$ \& tipDiario $=1 \#>$.

CAMPOS, R. A lanterna na popa: memórias. Rio de Janeiro: Topbooks, 1994.

CARSTENS, A. "My message to young people: stop trying to create money". BIS, 4th July 2018. Available at: <https://www.bis.org/speeches/sp180704a.htm>.

EICHENGREEN, B. et al. Rethinking Central Banking. Washington: Brookings, Sept. 2011. Available at: <https://www.brookings.edu/wp-content/ uploads/2016/06/Rethinking-Central-Banking.pdf>.

FINN, R. B. Memorandum of conversation, by the Third Secretary of the Mission in Japan (Finn). In: CLAUSSEN, P. et al. (Ed.). Foreign relations of the United States, 1951, Asia and the Pacific, volume VI, part 1. Washington: USGPO, 1977a. (Document, n. 605). Available at: <https://history.state.gov/ historicaldocuments/frus1951v06p1/d605>.

Memorandum of conversation, by the Third Secretary of the Mission in Japan (Finn). In: CLAUSSEN, P. et al. (Ed.). Foreign relations of the United States, 1951, Asia and the Pacific, volume VI, part 1. Washington: USGPO, 1977b. (Document, n. 612). Available at: <https://history.state.gov/ historicaldocuments/frus1951v06p1/d612>.

FRALEIGH, C. A. Memorandum by the officer in chargé of economic affairs in the Office of Northeast Asian Affairs (Hemmendinger) to the deputy to the consultant (Allison). In: CLAUSSEN, P. et al. (Ed.). Foreign relations of the United States, 1951, Asia and the Pacific, volume VI, part 1. Washington: USGPO, 1977. (Document, n. 565). Available at: <https://history.state.gov/ historicaldocuments/frus1951v06p1/d565>. 
IMF - INTERNATIONAL MONETARY FUND. Bank for International Settlements: its functions and prospects. Washington: IMF, 19 Aug. 1948. (Press Report, n. 48/25). Available at: <https://archivescatalog.imf.org/Details/ archive/125060875>.

I 300 Bank for International Settlements: 1947-1963. Washington: IMF, 1963. Available at: <https://archivescatalog.imf.org/Details/archive/110092116>.

. I300 Bank for International Settlements: 1964-1966. Washington: IMF, 1966. Available at: <https://archivescatalog.imf.org/Details/archive/110092118>.

. I300 Bank for International Settlements: 1967-1970. Washington: IMF, 1970. Available at: <https://archivescatalog.imf.org/Details/archive/110092119>.

Bank for International Settlements (BIS): 1985-1990. Washington: IMF, 1990. Available at: <https://archivescatalog.imf.org/Details/archive/110014982>.

KAYSEN, C. Letter from the chairman of the Task Force on Foreign Economic Policy (Kaysen) to president Johnson. In: DUNCAN, E.; PATTERSON, D. S.; YEE, C. (Ed.). Foreign relations of the United States, 1964-1968, volume VIII, international monetary and trade policy. Washington: USGPO, 1998. (Document, n. 18). Available at: <https://history.state.gov/historicaldocuments/ frus $1964-68 \mathrm{v} 08 / \mathrm{d} 18>$.

LEBOR, A. Tower of Basel: the shadowy history of the secret bank that runs the world. Santa Barbara: Public Affairs, 2013.

NIEMEYER, O. E. Reorganizaçáo das finanças brasileiras. Rio de Janeiro: Ministério da Fazenda; Imprensa Nacional, 1931. Available at: <http://www.gustavofranco.com. br/uploads/files/Relatorio\%20Otto\%20Niemeyer\%201931.pdf>.

SCHENK, C. R. Coordination failures during and after Bretton Woods. In: GHOSH, A. R.; QURESHI, M. S. (Ed.). From Great Depression to Great Recession: the elusive quest for international policy cooperation. Washington: IMF, 2017. p. 69-89.

The governance of the Bank for International Settlements, 1973-2020. In: BORIO, C. et al. (Ed.). Promoting global monetary and financial stability: the Bank for International Settlements after Bretton Woods, 1973-2020. Cambridge: Cambridge University Press, 2020. p. 46-93. Available at: <https:// doi.org/10.1017/9781108856522.004>.

SVERIGES RIKSBANK. Annual report for Sveriges Riksbank 2018. Stockholm: Sveriges Riksbank, 2019. Available at: <https://www.riksbank.se/ globalassets/media/rapporter/arsredovisning/engelska/annual-report-2018.pdf>. 
TONIOLO, G. Central Bank Cooperation at the Bank for International Settlements, 1930-1973. New York: Cambridge University Press, 2005.

WILEMAN, J. P. Brazilian exchange: the study of an inconvertible currency. Buenos Aires: Galli Bros, 1896. Available at: <http://www2.senado.leg.br/bdsf/ handle/id/518736>.

YAGO, K. The financial history of the Bank for International Settlements. London: Routledge, 2012. 
